\title{
Implications of Regional Autonomy for National and Local Coal Mining Development Companies: Case Study of The closure of PT. BA-UPO in Sawah Lunto, West Sumatra
}

\author{
Ade Saptomo \\ Faculty of Law \\ Pancasila University \\ Jakarta, Indonesia \\ adesaptomo@univpancasila.ac.id
}

\begin{abstract}
This paper aims to analyze the relationship between the implementation of regional autonomy policy with the National Coal Mining Company and the emergence of the Local Coal Mining Company in Indonesia with a particular case study on the case of coal for mentioned Coal located in Sawah Lunto, West Sumatra. As a national mining company that has been experienced and producing since 1867 , had been closed 2017, one side, and another one, local companies are allowed. This phenomenon is important for taking portray the legal relationship between the implementation of regional autonomy, the birth and death of the development of mining companies in the era of regional autonomy. With the case of mining in Sawah Lunto, the question is whether the implementation of regional autonomy has implications for opportunities or constraints for mining companies, is there a conflict between the national mining companies and local communities so that local companies arise, and how to solve them. The question is answered through field research to further discuss the related legal, social and cultural aspects that have implications for the development of coal mining. The result is a description that describes a legal policy should accommodate the socio-cultural aspects of the local community.
\end{abstract}

Keywords - law, regional autonomy, company, local culture

\section{INTRODUCTION}

Regional autonomy was launched following the fall of the New Order government in 1998, a set of laws on which the law of the regional autonomy movement was issued, among others, the Regional Government Law Number 22 of 1999 , but later in its implementation caused confusion in the absence of local actors and organizers not ready, some clauses open a new interpretation space that tends to encourage a resurgence of regional sentiments. Whereas that is not entirely a resurrection of regional sentiments, but how local governments are able to manage and utilize the potential of surrounding natural resources to increase local revenue so as to improve the welfare of the people he leads.

Five years later, the law was revised into Law Nu mber 32 Year 2004 which regulates the same. The essence of the law is still the same, namely encouraging local governments to explore and exploit the potential of natural resources in order to improve the welfare of its people. One of the implications of the implementation of regional autonomy is the rise of local governments and local society to access local natural resources.

One of the Natural Resources is coal mining Perseroan Terbatas Unit Pengelola Ombilin (PT. BA-UPO) located in Sawah Lunto, West Sumatra, for example, which was established since the Dutch Colonial Era in 19th century partly influenced the implementation of regional autonomy, although it has long been known as one of the main coal producer in Indonesia. Coal mine plays an important role in the provision of energy sources for railways, fireballs and industrial purposes. The Government's policy of using coal for industrial activities in Indonesia, the municipalities' situation improved again after a long period of sluggishness due to the abundance of comparis on and the cheapness of oil prices in the market.

With the regional autonomy, the assumption is that there is an increase in production considering that PT. BA-UPO gets legitimacy to increase its production, but the fact showed other condition, where mentioned PT. BA-UPO which was still in production in 2015, but in the year 2017 is not production, UPO 1 and 2 closed. The question is whether there is a legal relationship between the implementation of regional autonomy with the closing and opening of the development of coal mining companies, in this case PT. BAUPO on the one hand and other parties, i.e. local mining is allowed.

\section{RESEARCH QUESTION AND METHOD}

With the case of coal mining in Sawah Lunto, the question is whether the implementation of regional autonomy has implications for opportunities or constraints for mining companies, is there a conflict between the national mining companies and local society so that local companies arise, and how to solve them. The question is answered through field research method to further discuss the related legal, social and cultural aspects that have implications for the development of coal mining in Sawah Lunto. 


\section{DAT A AND DISCUSSION}

Sawah Lunto is a mining town where its existence is not separated from the share of the Dutch Indies Government. When the Dutch colonizers first came to Indonesia in 1596 under Cornelis de Houtman, perhaps those concerned goals did not expect Indonesia's wealth beyond spices. In fact, Indonesia, then known as the Dutch East Indies, has more wealth than the previously mentioned herbs, which are nonrenewable natural resources such as coal. However, coal mining in Sawah Lunto has decreased substantially, especially after the regional autonomy policy has been implemented since 2002. At least the existing mining model in Ombilin, Sawah Lunto can be described as follows.

\section{A. Coal Nagari Sijantang}

One of nagari in Sawah Lunto is Nagari Sijanjang. The formation of the village of Sijantang is similar with other nagari in Minangkabau community. There are number of tribes embedded into the Kerapatan Adat Nagari. In relation to the natural resources potential, Nagari Sijantang has coal mineral content as well. Potentially, the coal resources are the hak ulayat of the local society. Among them, Rantiah Village, Sikalang Village, Salak Village, Sijantang Koto Village, Datar Mansiang Village. The overall location of the mine, since the first mining was done by PT. BA-UPO and but currently has been controlled by local society with the status of people mining or Coal Nagari Sijantang.

\section{B. Conflict of PT. BA-UPO versus Local Society}

Local Society (Indigenous Peoples) of Nagari Sijantang stated that coal mines managed by PT. BA-UPO is located in the ulayat area of Sijantang Nagari. The concept of natural resource management according to local custom has been applied since the Dutch Colonial Government, which, according to Notariate Acte 27 July 1896, the concession holder pays $10 \%$ of the net profit to the local people at a maximum of $\mathrm{F} 40000$. This agreement indicates that The Dutch Colonial Govern ment recognizes the existence of hak ulayat of local society.

However, after the coal mine of PT. BA-UPO which has the authority power of Mining, the agreement is not fulfilled, even claimed as the wealth of the State. In addition, the effort to close the local people's mining is done by involving Ninik Mamak, but the local people consider that the land where coal mining by PT. BA-UPO is the ulayat land of Ninik Mamak Rantiah (tribe). As a result, a few Ninik Mamak participate in the excavation and mining of coal on ulayat that has been controlled by PT. BA-UPO, although such activities are prohibited activities because it harms the State and the miner's selves.

Substantially Indonesian culture contains the cultural themes contained in the conflict/Dis pute Settlement based on local potential. To name some of them is bulek aia dek pambuluah, bulek kato dek Mufakat (deliberation) in Minangkabau society, for Dispute Settlement based on the local potency. Cultural themes are actually present and are often used in Dispute Resolution based on local potentials occurring in Sawah Lunto, in this context in Nagari Sijantang, es pecially in small scope, where in the small scope face-to-face identity is more prominent than complex societies.
In each of these areas have cultural themes that are basically between each other the same substance that is upholding the culture of deliberation (musyawarah). In Minangkabau society for example, there is a density institute of nagari customs, that is Nagari Sijantang.

\section{Regional Autonomy and its implication}

When the regional autonomy policy was launched after the fall of the New Order Government in 1998, a set of laws on which the law of the regional autonomy movement was issued, one of them is Law Number 22 Year 1999 on the regional Government. The policy is intended to authorize local governments to utilize the potential of resources in the region to increase local revenue, particularly for the welfare of the people. Five years later, such law was revised into Law Number 32 Year 2004 which regulates the same material. The core of the law is still the same that is encouraging local governments to improve the welfare of the people in their respective regions. Implementation of regional autonomy has implications, for instance, the rise of local governments to explore the potential of local resources and the local people have an effort to do improve their prosperity by their ways as well.

\section{Closure and Opening of Mining}

Since the 1990s the company has conducted research to measure the economic value of coal production in Ombilin area. As a result, Ombilin's production is no longer economical for the company. Even the cost of production soared to 1.4 million US dollars per year. In fact, the newly acquired Ombilin coal reserves of 23 million tons, of total reserves of 102 million tons. Such conditions, causing mining operations in Ombilin, both 1.2, in the Era of Autonomy Region has begun to stop since 2017.

Other reason, the cessation of production due to expensive production costs, higher than the selling price of coal. The coal reserves in Ombilin are on average at a depth of 800 meters below ground level. This condition requires more sophisticated technology to dredge coal in deeper depths. This could make Bukit Asam lose up to IDR 53 billion per year. Currently, the company is trying to find a partner who can reduce production costs. The current condition, the cost of coal production in Sawah Lunto is much higher than the selling price.

There is a possibility if anyone has the technology and cheap, this closure will be reviewed. Therefore PT. BA will seek partners from abroad to work on Ombilin 3. PT. BA still keeps the intention to continue the production of coal at the mining site Ombilin 3, Sawah Lunto, West Sumatra with the cooperation of a company capable of mining coal with more production costs cheap. PT. BA also plans to extend the Mining Business License (IUP) on Ombilin 3. At the time of PT. BA experienced a decline with a variety of reasons as above mentioned, also born a local mining company that encouraged the atmosphere of regional autonomy.

Since 2010 until 2015 there are 12 coal mining companies that have Mining Business License (IUP) in Sawah Lunto issued by local government. Based on Article 73 Act Number 4 Year 2009 on Mineral and Coal Mining, that (1) The district / municipal governments shall carry out guidance in the field exploitation, mining technology, as well 
as capital and marketing in an effort to improve the capability of the people's mining business.

\section{CONCLUSION}

There is the legal relationship between the implementation of regional autonomy, the closure and opening of the development of mining companies in the era of regional autonomy. The implementation of regional autonomy has implications (1) opportunities for local societies, and (2) constraints for national coal mining companies, (3) conflict between the national mining companies and local communities are not solved by local culture. So that, all implication should be settled through the socio-cultural principles due to the good law is not separated from its social and cultural principles where it existence.

\section{REFERENCES}

[1] LBH-Padang, 2005. Kearifan Lokal Dalam Pengelolaan Sumber Daya Alam, Padang: INSIST Press

[2] PT. BA - UPO, 1992. 100 Tahun Tambang Batu Bara Omblin Sumatera Barat 1891-1991. Sawah Lunto, PT. Tambang Batubara Bukit Asam (Persero) Unit Pertambangan Ombilin

[3] Saptomo, Ade, 2004. Potensi Lokal Dalam Penguasaan Tanah dan Pemanfaatan Sumber Alam, www.Huma.or.id. p1 